P-011

\section{腹腔鏡下（体外式）による卵巣腫瑝核出術に おけるセプラフィルムの使用方法}

市立砺波総合病院産婦人科

○伏木 弘、生駒友美、吉本英生、大田 悟

産婦人科領域においてARTをはじめとする不妊 治療は目覚ましい進歩を遂げている。しかし、妊 孕性のある女性に腹腔内の手術をするときは、術 後の癒着をできる限り避けなくてはいけない。今 までに帝王切開におけるセプラフィルムの使用法 について報告しました。今回、腹腔鏡下（体外式） による卵巣腫瘍核出後の瘉着防止のためのセプラ フィルムの使用法を考案したので報告する。

対象症例は、画像診断あるいは腫瘍マーカーな どより明らかに悪性腫瘍が否定できる成熟奇形 腫、粘液性囊胞腺腫、槳液性囊胞腺腫などの症例 に対して、腹腔鏡下（体外式）による卵巣腫瘍核 出術を行う場合にセプラフィルムを 1 枚使用す る。セプラフィルムの使用方法は、卵巣囊腫核出 後に十分に止血ができているか確認し、また修復 した卵巣の表面よりガーゼでふき取り、乾燥する 前にセプラフィルムを適当な大きさに切、サラン ダップを巻くように全周性に巻きその後約 30 秒ぐ らい経過してから用手的に腹腔内へ完納する。こ の時は腹壁に切開創が $1.5 \mathrm{~cm}$ ぐらいでも腹腔内に 完納した卵巣よりセプラフィルムは剥離しておら ず、またさらにその後の腹腔内の十分な洗浄に対 してもセプラフィルムは剥離していなかった。

この方法によると、腹腔鏡下（体外式）による 卵巣腫瘍核出術を行う場合にセプラフィルムの使 用が可能でありさらにインターシードと異なり術 後に移動したりしなくて非常に有用と考えられ た。
P-012

\section{皮様車腫の腹腔鏡手術の適応について}

三重大学産科婦人科

○近藤英司、菊川東洋、杉山隆、佐川典正

【目的】良性腫瘍である皮様囊腫は、若年で発見 されることも多く、腹腔鏡を選択することも少な くない。皮様囊腫と診断しても稀に悪性転化や未 熟奇形腫を経験することがある。しかし、現在の 卵巣悪性腫瘍に対する腹腔鏡手術は、最近の卵单 癌取り扱い規約では積極的に導入するという状況 には至っていない。そこで皮様囊腫の術前診断を 再検討し、腹腔鏡手術の適応について検討した。 【方法】2000年 1 月からの 5 年間において当院で 術前にGerm cell tumorと診断し手術（開腹手術 79例、腹腔鏡手術25例）を行った104例について レトロスペクティブに検討した。

【結果】摘出病理組織で皮様囊腫100例・未熟奇形 腫 3 例 - 成熟奇形腫の扁平上皮癌化 1 例と診断さ れた。臨床所見の特徴としては悪性 4 例中 3 例に 急速な腹部膨満所見を認めた。画像診断において 未熟奇形腫 1 例 - 成熟奇形腫の扁平上皮癌化 1 例 は術前から鑑別できたが未熟奇形腫の 2 例は皮様 囊腫と診断しており、その内の 1 例は腹腔鏡によ る手術を行った。良性群（n=100）では最大腫

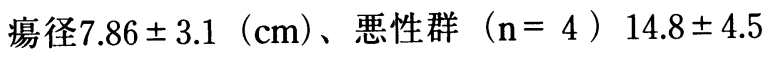
(cm) となり悪性群 4 例すべてが $10 \mathrm{~cm}$ 以上であ った。MRI所見で未熟奇形腫 3 例は脂肪組織の点 在が術後の再検討で確認できた。また腫痬マーカ 一值は良性群 SCC $1.5 \pm 2.1 （ \mathrm{ng} / \mathrm{ml})$ 、覀性群 SCC2.9 2.7 とやや悪性群で高值を示す傾向を認 めたが良性群でも腫瘍径が $10 \mathrm{~cm}$ 以上（23例）の 症例では、SCCが高值 $(9 / 23)$ を示す傾向にあ った。その他の腫瘍マーカーに優位差はなかっ た。

【結論】皮様囊腫において急速な腫瘍の増大・腫 瘍径 $10 \mathrm{~cm}$ 以上. MRI上脂肪組織の点在の症例で は悪性の可能性も十分考慮にいれるべきである。 


\section{偶発的に発見された子宮内膜症合併中皮増殖 症mesothelial hyperplasiaの一例}

\section{獨協医科大学産科婦人科学教室}

○北澤正文、深澤一雄、西川正能、大石 曜 岡崎友紀、望月善子、稲葉憲之

【緒言】胸腔、腹腔などの体腔を被覆する漿膜細 胞は中胚葉に由来する上皮様細胞で中皮 mesothel と呼ばれており、卵巣の中皮増殖症 mesothelial hyperplasiaは比較的まれである。今回我々はクラ ミジア感染による卵管留血腫と診断し卵管切除を 行った結果、実際には付属器が切除され、偶発的 に発見された子宮内膜症を合併した中皮増殖症の 一例を経験したので報告する。

【症例】29歳、一回経産婦。家族歴、既往歴に特 記すべきことなし。月経困難と続発性不妊を主訴 に来院した。経胵超音波で診察したところ左付属 器に一致して直径 $6 \mathrm{~cm}$ のチョコレート襄胞を認 め、MRIでの所見も同様であった。しかし、腫瘍 マーカーは、CEA:1.1、CA19-9:26、CA125:14、 SCC:0.5以下でいずれも正常值であった。不妊の 原因検索およびチョコレート襄胞の核出を目的に 腹腔鏡下に手術を行ったところ、囊胞は卵巣では なく卵管留水腫（内容はチョコレート状）を思わ せる形態をとっていた。また、肝周囲には、FitzHugh-Cartis症候群を思わせる膜状の癒着を認め た。これらの結果、術前のクラミジア抗原検査は 陰性であったが、クラミジア感染による左卵管留 血腫と判断、左卵管切除を行った。しかし、術後 クラミジア抗体を測定した結果、IgG、IgAいず れも陰性で、また、病理診断では卵管はほほ正常、 子宮内膜症性囊胞を認めるものの卵巣の中皮増殖 症mesothelial hyperplasiaとの結果であった。 【結語】腹腔鏡下の肉眼的所見でクラミジア感染 による左卵管留血腫と診断し、左卵管を摘出した。 しかし、摘出されたのは左付属器で左卵管は正常 であった、この結果、偶発的に子宮内膜症合併中 皮增殖症mesothelial hyperplasiaの一例を経験し た。

\section{当科で腹腔鏡下手術を行った卵巣成熟震胞奇 形腫の検討}

広島赤十字原爆病院産婦人科

○高取明正、石田 理、小川達博

【目的】卵巣囊胞奇形腫は最も手術機会の多い良 性卵巣腫瘍のひとつであるが、悪性転化や、術後 の腫瘍内容遺残による化学的腹膜炎などの合併症 が報告されている。当科においても未熟奇形腫と セルトリ細胞腫との合併例を経験したので報告す る。また、手術術式別に、腫瘍径・油成分の割 合・腫瘍漏出の程度と術後の発熱の有無について 検討した。全例手術終了前に腹腔内を十分洗浄し、 腫瘍内容の遺残物を最小限にするよう努力した。 【対象】当科で過去約 7 年間に腹腔鏡下に囊腫摘 出または付属器切除を行った 44 症例。（体外法で の囊腫核出23例、体内法での襄腫核出 15 例、付属 器摘出 6 例)

【結果】術後に 3 日間以上発熱した症例が 4 症例 あったが、特に腫瘍径、油成分の割合、漏出の程 度と術後の発熱に関連はなく、腫瘍内容の遺残を 最小限にすることで、化学的腹膜炎は予防可能と 思われた。しかし、未熟奇形腫症例とセルトリ細 胞腫との合併症例に関しては術前と術中の注意深 い観察によりその存在が予測された可能性があっ た。また全例に何らかの内容漏出があり、それを 最小限にする努力が必要と考えた。 


\section{卵巣腫瘍における腹腔鏡下手術の適応に関す る検討}

国家公務員共済組合連合会 浜の町病院

\section{卵巣子宮内膜症に対する腹腔鏡下polycys- tectomy後に卵巣癌と診断された 1 例}

\author{
石川県立中央病院産婦人科
}

【目的と方法】悪性卵巣腫瘍に対する腹腔鏡下手 術は、術中被膜破綻や port site metastasisなどの 問題点により、一般的には腹腔鏡下手術の適応と はされていない。従って卵巣腫瘍の手術法の選択 に際しては、術前診断が非常に重要である。卵巣 腫瘍の術前診断は超音波検査、MRI、CT、腫瘍 マーカーを組み合わせて行った。当科では良性と の術前診断をした場合、積極的に腹腔鏡下手術を 施行し、悪性が疑われた場合は腫瘍専門施設へ紹 介する方針をとっている。今回、平成12年 4 月か ら平成16年 8 月までの 4 年 4 か月間で、悪性では ないとの術前診断で当科にて手術を施行した 1,475例（A群）（このうち腹腔鏡下手術は1,266例） および悪性を疑い腫瘍専門施設に紹介した 36 例 （B群）を対象とし、卵巣腫瘍診断の組織分類お よび精度について後方視的に検討し、卵巣腫瘍が 腹腔鏡下手術の適応として妥当かどうかを評価し た。卵巣腫瘍の術前診断は超音波検査、MRI、 CT、腫瘍マーカーを組み合わせて行った。

【結果】A群の術後診断は良性が1,454例 $(98.6 \%) 、$ 境界悪性が21例 $(1.5 \%) 、$ 悪性がゼロだった。こ のうち腹腔鏡下手術施行例では、良性が 1,256 例 $(99.2 \%)$ 、境界悪性が10例 $(0.8 \%)$ であった。組 織別の正診率 (術前診断に対する術後診断の割合) は内膜症性囊胞では $95.0 \%$ 、皮様囊腫では $98.5 \%$ 、 漿液性囊胞腺腫では $79.7 \%$ 、粘液性襄胞腺腫では $56.5 \%$ でった。B群の術後診断は悪性が20例 $(60.6 \%)$ 、境界悪性が 5 例 $(15.2 \%)$ 、良性が 8 例 (24.2\%) だった。これらを基に計算すると卵巣 腫瘍の術前診断の精度は、感度が $100 \%$ 、特異度 が $99.1 \%$ 、陽性的中率が $60.6 \%$ 、陰性的中率が 100\%だった。

【結論】臨床的には、十分な術前診断精度であっ た。今後も術前に悪性が疑われない卵巣腫瘍症例 に対しては、積極的に腹腔鏡下手術を選択してよ いと考えられた。
○佐々木博正、干場 勉、平吹信弥、篠倉千早 前川真知子、齊藤里奈、吉成秀夫、石川博士 朝本明弘

【背景】当科では開腹手術既往の有無に関わらず、 挙児希望のある場合には腹腔鏡下手術を積極的に 行っている。今回、3 回目の卵巣子宮内膜症手術で 卵巣癌と診断された 1 例を経験したので報告する。 【症例】36歳 1 回経妊 1 回経産。26歳で第 1 子分婏。 挙児希望のため32歳で近医産婦人科を受診。両側 チョコレート襄腫と診断、開腹両側卵单腫瘍摘出 術後、不妊治療を受けたが妊娠せず。35歳で転医、 左チョコレート襄腫を再び指摘され、開腹にて 2 回目の左卵巣囊腫摘出術 (右卵巣は癒着のため確 認できず)。術後は 6 ケ月間のGnRHa療法後、夕イ ミング指導等で経過観察。翌年、再度、左の卵巣チ ヨコレート襄腫を指摘され当科初診した。内診、経 腟超音波検查・骨盤MRIで、左卵巣チョコレート襄 腫(画像上は悪性所見なし)および子宮筋腫と診断、 既に 2 回の手術療法且つ 1 回のGnRHa療法後で、 挙児希望のあること、前回手術時に右卵巣の状態 が未確認であったことから、まず手術療法を優先 した。今回は全て腹腔鏡下に実施した。骨盤腹膜は 平滑、腹水細胞診は未実施。左卵巣は卵管と強固に 癒着、腫大なし。右卵巣腫瘍は広間膜後葉、仙骨子 宮勒帯との間で内膜症性癒着あり、癒着剥離の際 に被膜破綻。濃茶色内容を吸引除去後、体内法で䡛 腫壁核出、核出創を縫合。腹腔鏡下子宮筋腫核出術 を併施し、著変なく手術を終了。病理組織診断で囊 腫壁に明細胞腺癌部分を認め、後日、腹腔鏡下傍大 動脈〜骨盤リンパ節郭清および胵式子宮全摘術 + 両付属器摘出術施行。腹水細胞診は陰性、摘出物に は腫瘍の残存・転医を認めず、最終的にstage Icと 診断、術後化学療法を実施した。

【考察】子宮内膜症の治療には複数回の手術が必要 になる場合がある。各術前に悪性腫瘍の可能性を 十分検討すべきであるが、全てを事前に診断する のは不可能である。一方、術中被膜破綻のIc期は比 較的予後良好との報告もあり、腹腔鏡下手術で全 て対処可能な場合もあると思われた。 


\section{卵巣腫場の術前診断精度に関する検討 410 年 前と現在との比較山}

九州大学病院産科婦人科

○上岡陽亮、中村博子、内田聡子、田中義弘 野崎雅裕

【目的】術前評価法の進歩に伴い、卵巣腫瘍にお いて術前診断精度が向上しているかどうかを検討 した。

【方法】 2003 年の 1 年間と 10 年前の 1994 年の 1 年 間に卵单腫瘍を疑われて当科で初回手術を施行 し、組織学的に診断がなされた症例を対象とした。 病歴・症状・理学所見・腫瘍マーカー・画像所見 をもとに総合的に下した術前診断と施行術式・術 後診断について後方視的に検討した。

【成績】10年間でCTはへリカルCTに、MRIは脂 肪抑制併施や高速シークエンス化といった画像診 断法の変化があった。10年前の症例133例のうち 術前に悪性を強く疑ったのは29例で、組織学的に 悪性（境界悪性を含む）であったのが27例であり、 陽性的中率は $93.1 \%$ 、陰性的中率は $85.1 \%$ であっ た。2003年の症例121例では術前に悪性を強く疑 ったのは33例、組織学的に悪性であったのが 32 例 で陽性的中率は $96.9 \%$ 、陰性的中率は $81.2 \%$ であ り、42例 $(34.7 \%)$ において腹腔鏡下手術を施行 した。良性腫瘍における診断感度は皮様囊腫で10 年前の $51.3 \%$ から $77.4 \% に$ 、子宮内膜症性囊胞で 40.0\%から53.8\%に向上していた。

【結論】良・悪性に関する術前診断の精度は 10 年 前と現在で同等であった。術前に良性を強く疑っ た症例において 5-6\%が悪性腫瘍（境界悪性を 含む）と依然として術前診断に限界があり、適切 な術式を遂行するためには術中迅速病理組織診断 を行うことが不可欠と考えられた。皮様囊腫と子 宮内膜症性襄胞についての術前診断精度は向上し ており、術式（腹腔鏡下手術）の選択において有 利な情報となりえた。

\section{子宮附属器茎捻転を発症した多囊胞性卵巣症 候群の一例}

鳥取大学医学部産科婦人科

○大濱陽子、池田綾子、渡邊彩子、田頭由紀子 竹中泰子、庄司孝子、大畠順恵、光成匡博 吉田壮一、片桐千恵子、岩部富夫、原田 省 寺川直樹

多囊胞性卵巣症候群（以下PCOS）患者で、卵 巣刺激を行っていない自然周期に付属器茎捻転を 発生した症例を経験したので報告する。患者は、 32歳、経妊 1 回、自然流産 1 回。初経は12歳で、 それ以後月経は不順であった。突然の下腹痛を主 訴に当院救急外来を受診した。CT検查で径 $8 \mathrm{~cm}$ の腹腔内腫瘤を認めたため、当科紹介入院となっ た。入院時には疼痛は自制内となっていた。下腹 部に手拳大の腫瘤を触知し同部に軽度圧痛を認 め、下顎には男性様の多毛を認めた。超音波検査 で右卵巣は径 $8 \mathrm{~cm}$ に腫大、左卵巣は約 $4 \mathrm{~cm}$ に腫 大し多数囊胞状を呈していた。検査所見は白血球 10900、CRP陰性、貧血はなかった。尿中hCG定 性は陰性で、腫瘍マーカーは正常であり、 LH/FSH比が1.83であった。MRIでは腫大した右 卵巣は鬱血または浮腫による変化を認め、左卵巣 は多襄胞性卵巣の所見を呈していた。翌日にダグ ラス窩貯留液の増加と、ダグラス窩穿刺で腹腔内 出血を認めたため緊急腹腔鏡下手術を施行した。 右卵巣は腫大して 360 度捻転しており、暗赤色を 呈していた。表面は一部破綻し、同部から出血し ていた。左卵巣は $4 \mathrm{~cm}$ 大に腫大し、多数の小囊 胞を認めた。右付属器摘出術後、左卵巣の小囊胞 をKTPレーザーにて焼灼した。右卵巣の病理組織 検査は黄体出血であった。2 カ月後に自然妊娠が 成立し、妊娠経過は順調であり正常経腟分婏した。 卵巣刺激を行っていないPCOSの付属器茎捻転の 発生は稀であり、確定診断に苦慮した。急性腹症 では非腫瘍性病変の付属器茎捻転も念頭に置く必 要があり、挙児希望のある女性に対しては妊孕能 の温存・回復を考慮した迅速な対処が必要とされ ることを再認識した。 
P-019

\section{卵巣アンドロゲン産生腫瑒の 1 例}

福岡大学医学部産婦人科

○福岡三代子、井上善仁、貞森理子、辻岡寛 蜂須賀 徹、瓦林達比古

卵巣アンドロゲン産生腫瘍は、全卵巣腫瘍の $0.2 \%$ 以下の稀な腫瘍であり、アンドロゲン過剩 分泌に基づく男性化症状および脱女性症状が $1 / 3$ の症例でみられる。今回男性化症状を伴う卵巣ア ンドロゲン産生腫瘍に対して腹腔鏡下手術を行っ た症例を経験したので報告する。症例は、31歳、 未婚で未経妊。主訴は月経不順、多毛。24歳頃か ら多毛で、顔面と腕は永久脱毛を受けた。26歳ま で月経整順であったがその後不順となり 2 ヶ月に 1 度、持続 3 日程度となった。30歳になって更に 不順になったため前医受診。陰核肥大、多毛を認 め、テストステロン $175 \mathrm{ng} / \mathrm{dl}$ と高值であったため 当科紹介受診となった。身長 $158 \mathrm{~cm}$ 、体重は $51 \mathrm{~kg}$ で皮膚線条やBuffalo hump、顔面の多毛・ニキビ は認めなかった。陰毛はTanner期、径 $15 \times 10 \mathrm{~mm}$ の陰核肥大を認め、内診上子宮体部は鶏卵大で両 側付属器触知せず。経胵超音波検査では左卵巣に 径 $18 \times 19 \mathrm{~mm}$ の辺縁明瞭な充実性腫瘍を認めた。 骨盤MRIでも左卵巣に径 $2 \mathrm{~cm}$ の充実性腫瘍あり。 胸腹部MRIでは副腎に明らかな腫瘍性病変なし。 内分泌学的検查所見では LH $12.5 \mathrm{mIU} / \mathrm{ml}, \mathrm{FSH}$ $7.8 \mathrm{mgIU} / \mathrm{ml}, \mathrm{PRL} 5.4 \mathrm{ng} / \mathrm{ml}$, testosterone373ng/dl, DHEA-S1900ng/ml,. ACTH28pg/ml,cortisol11.g/ $\mathrm{dl}, 17-\mathrm{KS} 9.0 \mathrm{mg} / 1,-17$ a OHP4.4ng/mlであった. 左 卵巣アンドロゲン産生腫瘍と診断し、腹腔鏡下左 付属器切除術施行。卵巣表面からは腫瘍の有無は 不明であった。術後病理検查でSertoli-Leydig cell tumor with intermediate differentiationであった。 術後 8 日目テストステロン $46 \mathrm{ng} / \mathrm{dl}$, 術後 4 ケ月 $36 \mathrm{ng} / \mathrm{dl}$ と正常值している。

【結語】卵巣アンドロゲン産生腫瘍は稀な卵巣腫 瘍であり、比較的若い女性に発症し、脱毛・エス テ等により、多毛・にきび等の典型的症状を認め ない場合があるため、慎重に内分泌検査や画像検 查を行う必要があると思われる。
P-020

\section{当科の多囊胞性卵巣症候群の腹胵鏡下卵巣焼 灼術 (Laparoscopic ovarian drilling) の 有無においての検討}

\author{
佐久市立国保浅間総合病院 産婦人科 ${ }^{1)}$ \\ 三浦産婦人科 ${ }^{2)}$ \\ ○堀祐子 ${ }^{11}$ 、須藤祐美子 ${ }^{1)}$ 、高橋慎一朗 ${ }^{1)}$ \\ 三浦秀輔 ${ }^{2)}$
}

【目的】不妊症例における多襄胞性卵巣症候群 (PCOS) は、排卵障害や排卵遅延による卵の質 の低下を認め、また排卵誘発剂使用時に卵巣過㮃 刺激症候群 (OHSS) の発症や多胎妊娠の発生な どを起こしやすい。今回われわれはクロミフェン 無効例におけるPCOS合併不妊症例に対しての腹 腔鏡下卵巣焼灼術（Laparoscopic ovarian drilling） （LOD）施行の有無と妊娠予後について検討した。 【方法】対象は、1998年 7 月から2005年 1 月まで、 当科でクロミフェン無効例におけるPCOS合併不 妊症例に対して腹腔鏡下卵巣焼灼術（LOD）を 施行した11名とクロミフェン無効例における PCOS合併不妊症例に対しての手術未施行例 9 名 を対象とした。クロミフェン無効例にはLH含量 の少ないhMG製剂を用いたステップアップ法で 排卵誘発を行ない、hCG投与量は最小限とした。 drillingは電気メス（モノポーラー）にて両側卵 巣表面に小孔を10から 20 箇所、切開または凝固モ ードにて行なった。

【成績】LOD施行例（11名）のうち、妊娠 6 名 $(54.5 \%)$ 。その内訳は、自然妊娠 2 例（1 例はク ロミフェン妊娠、分婏後の第 2 子目の自然妊娠)、 クロミフェン妊娠 4 例、hMG - hCG妊娠 1 例、 OHSS 1 例。妊娠 6 名は36週から41週で分婏。 4 名経腟分婏。 2 名産科適応で帝王切開。児に特に 異常なし。妊娠 6 名のうち 2 名は流産 1 例ずつ既 往。LOD未施行例（9 例）のうち妊娠 6 名（66.7 $\%)$ 、全例 hMG - hCG妊娠、OHSS 3 例。品胎 1 例。流産 1 例。(その後すぐ再びhMG - hCG妊娠) 妊娠 6 名のうち、現在妊婦検診中を除いた 4 名が 35 週から 40 週で分婏。うち 1 名が産科適応で帝王 切開。 3 名は経腟分婏。児に特に異常なし。

【結論】腹腔鏡下卵巣焼灼術は多胎やOHSSの頻 度が低く、有用であると思われた。妊娠率、分婏 経過についてはどちらも変化なかった。 